\title{
Nonequilibrium landscapes and nature conservation in the Białowieża Forest
}

\section{Agata Kowalewska}

\begin{abstract}
:
Traditional conceptualizations presume that landscape and nature in general are characterized by a striving for balance. In consequence, environmental protection chiefly consists in conservation of the existing state, without making allowances for the dynamic changes caused by vital processes taking place in those landscapes, human and non-human alike. The current dispute concerning the protection of the Białowieża Forest is nothing but an upshot of the differences between the involved with respect to what should be protected on top of how it should be done. This study outlines the problems deriving from conceptualizations of nature and landscape as static entities and comes forward with a proposal of conceiving landscape not as an "image of the land"1 but a corporeal experience of being in a space, on which climate change, civilizational and social transformation, political decisions, and bark beetles all have their impact.
\end{abstract}

Keywords:

nonequilibrium landscapes, nature conservation, nonhuman expertise, Białowieża Forest

\section{Introduction-Ips typographus}

This study attempts to reflect on the category of landscape and outline the ramifications of its two distinct conceptualizations for strategies of nature conservation. In these considerations, the ongoing, intense conflict regarding the Polish part of the Białowieża Forest will be employed here as a frame of reference. In autumn 2015, a plan was developed to increase logging in the forest to counter a massive population build-up of the European spruce bark beetle (Ips typographus), which infests spruces and contributes to tree death. The decisions of Lasy Państwowe (the General Directorate of State Forests), endorsed by the Ministry of Environment, were met

1 For Polish speakers this category makes additional sense, because in Polish krajobraz (landscape) comes from kraj (land, country) and obraz (image, picture). 
with protests from numerous governmental and non-governmental organizations dedicated to nature conservation, representatives of academic circles, and the public. Opponents criticized the logging increase and removal of trees, arguing that the spread of the bark beetle is a natural process which occurs in the forest at regular intervals and plays an important role there (Sokołowski 2002; Gutowski 2002), whilst advocating passive conservation of its ecosystem. This mode of protection had been implemented in the Białowieża National Park, where by 2015 the outbreak of the bark beetle had already began to subside. Criticism prompted by logging plans soon gained broader social support, manifesting through social media, ${ }^{2}$ demonstrations, and marches, ${ }^{3}$ while the then minister of environment, Jan Szyszko, faced particularly severe backlash. It soon became clear that the conflict went beyond the facts of biology, reaching into the domain of worldview (Szyszko 2017). Indeed, the situation is more lucid when approached not so much as a contrariety of diagnoses made by forest conservation experts, but as a fundamental, ontological discrepancy in how the sides of the conflict construe basic notions, such as nature or landscape. These discrepancies lead directly to divergent opinions on the present and envisaged future landscape of the Białowieża Forest, as well as the ways to protect it. Landscape is one of the key notions in the discourse of nature conservation, and the manner in which it is defined bears materially on specific solutions and legal regulations. The entire Polish part of the Białowieża Forest is classified as a protected landscape area, which additionally overlaps-entirely or in part-with other protection schemes, such as national parks, strict reserves, or Natura 2000 areas.

The classical approach to landscape, based on the fundamental dualism of culture and nature as well as an objective understanding of nature, still endures, both in broader discourse and in nature conservation, despite having been criticized already in the latter half of the 2oth century; in recent years, the departure from that paradigm has been almost complete. Now, the predominant approaches fuse the material-natural dimension with the cultural one (Ingold 2000; Wylie 2007), enabling landscape to be conceived as a space of life, both human and non-human. The European Landscape Convention, ratified by Poland in 2004, defines landscape as "an area, as perceived by people, whose character is the result of the action and interaction of natural and/or human factors" (Dz. U. 2006, no. 14, item 98). This approach highlights the human perspective as indispensable for the notion of landscape; in other words, landscape is embedded as a category in the human experience of space. Thus, it is not only an "image of the land" that the human may look at, but also a corporeal experience of being in a historically established space.

2 For example, Facebook pages such as Wierzęw Białowieżę (I believe in Białowieża), Kocham Puszczę (I love the Forest), and Obóz dla Puszczy (The camp for the forest) gathered thousands of followers.

3 For example, Marsz Entów (The March of the Ents) in January 2016, Warszawski Marsz dla Puszczy (Warsaw March for the Forest), and Łódzki Spacer w obronie Puszczy (Łódź Walk in the Defense the Forest) in June 2017. 


\section{The History of the Forest}

The Białowieża Forest is Europe's last lowland forest where primeval traits are still observed: a remnant of the forests which had once covered the North European Plain and have over time yielded almost everywhere to human expansion (Maris 2008). Approximately 10,000 years ago, a predominantly coniferous forest grew where the Białowieża Forest stands now, with spruces, pines, firs, and larches. Gradually, beeches, alders, and rowans appeared, and after another several thousand years the species composition in the forest approached the one seen today. However, the forest continues to change and, with the warming of the climate, it has begun to lose the characteristics of a taiga-type woodland and has begun to shift toward a composition typical of Central European mixed forests. The distinctive features of the Białowieża Forest include a very high percentage of old tree stands and an exceptionally high diversity of species and habitats, many of which are not found anywhere else (PTTK, n.d.). These well-preserved primeval features in the Białowieża Forest are attributed to a combination of numerous factors, natural as well as historical. These areas have never been densely populated, while intensive resource management began relatively late. The considerable thickness in conjunction with extensive wetland made the forest hardly accessible, thus providing safe habitats for large animals, especially the European bison, whose populations had already been decimated elsewhere in Europe in the Middle Ages. Paradoxically, the first known ordinances aimed at protecting the forest landscape from logging, land cultivation, and hunting were introduced to create hunting grounds for kings and dukes (Pracownia, n.d.). Though limited, agricultural activity in the forest affected and transformed some of its parts, creating new habitats; these may have been atypical for the area, but their existence is believed to have been one of the factors which enabled the survival of the bison population by increasing the amount of available food (Białowieski Park Narodowy, n.d.).

The forest is a chronicle recording the story of this part of Europe, with interwoven geological factors, climate changes, historical and social circumstances, partitions, wars, and political transformations. It is important to point out that, as the current crisis demonstrates, the forest is a living ecosystem in a constant state of flux and together with it changes its landscape, which is heterogenous and dependent on natural and human factors alike. As stated in the introduction, this text attempts to approach the crisis surrounding the Białowieża Forest as a clash of two perspectives: the foresters and the Ministry of Environment see the forest as a resource in Poland's project of sustainable development (Szyszko 2017), which requires active care and continuous nurturing by humans, whereas to the opponents of logging it is a mature ecosystem which, over thousands of years, developed mechanisms enabling it to tackle climate changes on its own, and the activity of the bark beetle is one of those (Mikulski 2016). 


\section{Beetles are uglier than butterflies}

In the domain of nature conservation, the discourse can sometimes be dominated by the aesthetic aspect, particularly when the debate becomes a public one and the goal is to gain the public support. In such a case, species and landscapes are evaluated, following which the more beautiful or interesting are given preference over the less likeable. The phenomenon - called greenwashing-is discussed by Jamie Lorimer in Wildlife in the Anthropocene $(2015,167)$. Building a conservation strategy by directing public attention to aesthetic aspects and charismatic species-that is, those that elicit positive responses in people, such as tigers, lynxes, or bisonentails the risk that visually unappealing beetles or fungi, whose significance for the ecosystem is not infrequently absolutely vital, will be ignored in the public debate. As for the conflict around the Białowieża Forest, its sides propagate different landscapes of the forest; materials publicized by the adherents of active protection predominantly feature photographs of a green, orderly forest composed largely of young, healthy trees, which are contrasted with images of dead spruces. ${ }^{4}$ On the other hand, advocates of passive conservation promote pictures of the forest showing fallen trees, windthrow, and high understorey, adding slogans such as "let the forest overgrow" on their posters (Karpieszuk 2017). The aesthetic layer is another token of the discrepancy between visions of the forest and its landscape entertained by either side.

Interestingly enough, the notion that the Białowieża Forest should be "tidied up" is not a new one. Henryk Sienkiewicz described his 1882 visit there as follows:

The belief that for the sake of the forest it should be left untouched is an erroneous one. Above all, it should be kept tidy, and how does the forest fare in that respect? One sees piles of trees here, lying over tremendous expanses, almost everywhere in fact. These mounds, decayed and rotten, rise up to several feet high. Over those, there tower colossal windthrows like houses. An old tree tears up the entire volume of earth caught in its roots. The pit its fall created gathers rainwater. It is a curious and a frightening sight that such sites present: the soil is ruptured and full of pitfalls, the trunks, the blowdowns and the dry, desperately twisted branches covered by moss or hideous damp fill the entire space; among the woody bedlam a bog shows through-everything disarrayed, broken, shattered, savage, dead, and rotting-there is your picture in a nutshell. Even the air is heavy, suffused with the stench of decayed wood and rottenness. (Sienkiewicz 1882, 39)

In Sienkiewicz, there is a palpable affective charge associated with the forest. It is largely positive, but a number of paragraphs, including the above description, evince pestilence that spreads death and atavistic fears of chaos. The forest reminds everyone that humans are never quite at home there; the landscape ceases to be friendly. The radical otherness of the deep forest often elicits rapture and respect, but it also

4 Such imagery was used, for example, during the conference "Puszcza Białowieska - mity, fakty i przyszłość" ("Białowieża Forest-Myths, Facts, and the Future”), held on March 12, 2016 at the Senate of the Republic of Poland. 
engenders uncertainty, fear, and repulsion in those who visit it. Fear of the uncontrollable otherness of the chaotic (from the human standpoint) landscape in the forest and the desire to bridle and subordinate it to a comprehensible order-conveyed by Sienkiewicz - seem to be one of the obstacles to reconciling the positions adopted by the opposing factions in the present-day conflict.

\section{The nature-culture dichotomy}

The differences in how landscape is construed are founded on the ontology of nature and its relationship with the human. That foundation determines the specific object of protection when new regulations are drafted (e.g., whether it is a particular species or the ecosystemic process) and drives the preference for active or passive modes of conservation. The stance of the adherents of active protection relies on the categorial dissimilarity between humans and nature, and they argue that natural environment is a resource that should be managed; here, the subject and the object are clearly distinguished. In the normative layer, the human is valued higher than the non-human, as explicitly stated in minister Szyszko's public speeches (Szyszko 2017). The nature-culture dichotomy has long been the binding paradigm in the studies of both culture and nature (Descola 1996; Ingold 2000); it was only the latter half of the 2oth century that saw the gradual spread of such conceptualizations of nature, environment, landscape, and their relation to humans where the radical division between nature and culture was challenged and attention was drawn to their interpenetrations and interdependencies (Haraway 2003). In recent years, a perspective presuming that nature (and, in consequence, landscape) is not an essentially static but a dynamic entity (Lorimer 2012; Zimmerer 2000) has been gaining ever greater popularity in disciplines that embark on conceptualizations of nature and conservation. The ramifications of that change are indeed numerous. As Karl Zimmerer observes in his paper on nonequilibrium landscapes, the balance of nature - previously a fundamental paradigm - is now questioned, even rejected, in some circles, having been replaced with dynamic processes, transformations, and trajectories (Zimmerer 2000, 356). The shift of the paradigm dictating our understanding of nature bears on our understanding of landscape, which thus becomes inherently mutable, volatile, and hybrid. This hybrid, dynamic ontology allows the proponents of passive protection to recognize non-human expertise in ecosystemic processes, and see the value as inherent in this old forest as a system, with its internal workings, from which we can learn.

\section{Practical implications}

Given advancing climate change, the classical approach to nature conservation has begun to fail and, despite intense human efforts, landscapes change. Meanwhile, 
the notions of nature and landscape as dynamic entities slowly gain firmer footing. Protection of nature, understood as preservation or conservation of the existing state, proves ineffectual in many places because internal processes and external factors do bring about changes in ecosystems. Actions aimed at preserving a landscape as it is are doomed to miscarry, or even lead to the disruption of spontaneous ecosystemic processes and, as a result, to a reduction of biodiversity.

Much seems to indicate that this is the case in the Białowieża Forest (Sokołowski 2002). Areas under forest management and active protection differ from those in the Białowieża National Park, where the spruce population, for instance, has systematically diminished since the establishment of the park a century ago. As Bogdan Jaroszewicz from the University of Warsaw's Białowieża Geobotanical Station suggests (Jaroszewicz 2016; Nauka w Polsce 2017), this is due to the climate warming and the decline of groundwater levels. These are adverse conditions for spruces, and they promote bark beetle infestations. If a high population of spruces were to be sustained in the Białowieża Forest, widespread sanitary logging would have to be carried out and a least $80 \%$ of the dead trees would have to be removed. ${ }^{5}$ According to Jaroszewicz, such actions would nonetheless prove ineffective in the long term, while the forest would lose its unique characteristics with each sanitary logging. Having adopted the viewpoint that nature is dynamic, conservation focuses on the continuity of ecosystemic processes and on sustaining biodiversity rather than on species or habitats, thanks to which ecosystems can be conceptualized as both changeable and resilient (Wesołowski et al. 2016). As climate, hydrological, and civilizational changes continue, the transformation of the forest landscape seems inevitable, but that does not spell the end of the Białowieża Forest. Ensuring the continuity of ecosystemic processes and preservation of the unique characteristics of the forest requires passive protection that, to a significant extent, consists in having confidence in non-human expertise and the spontaneous, self-regulating mechanisms of its ecosystem. This, in turn, requires curiosity about the subsequent stage of transformation, about how the forest will tackle the bark beetles and climate change, how it will look in ten, twenty, and a hundred years (Lorimer 2014).

\section{Conclusions}

Considering the difficulties resulting from static conceptualizations of landscape, the perspective suggested here adopts a notion of an inconstant and dynamic landscape which spans all the lives taking place therein, both human and non-human. In consequence, the category of landscape can embrace its other meaning - that is,

5 There is an interesting study which recapitulates the position of adherents of passive protection; its relevance is supported by the scientific authority of the authors, though it occasionally employs sharp rhetoric-see Wesołowski et al. (2016). 
the experience of being in a particular space. Landscape construed as an experience of communing with space enables development of a nature conservation strategy that eschews the picturesque or beauty, but still follows affective logic, which I understand after Lorimer as a mode of understanding, of feeling, and of engaging in relations directed towards nature, all of which derive from and remain inseparably linked to the corporeal experience of non-human charisma (Lorimer 2015, 35). Humans can therefore learn to build affective relationships. This perspectiveevinced in the European Landscape Convention-if propagated, would create the scope for introducing a range of novel solutions based on the coexistence of the human and the non-human, as well as introducing and recognizing non-human expertise and agency. In order for that to be feasible, one should necessarily learn sensibility to nature in its many forms and dimensions, including the sublime and beautiful actors, such as wolves and centuries-old oaks, along with the inconspicuous ones, such as Ips typographus, whose role is anything but unimportant.

\section{References:}

Białowieski Park Narodowy. n.d. "European bison Show Reserve." Accessed September 19, 2017. https:// bpn.com.pl/index.php?option=com _ content\&task=view\&id=67\&ltemid=119\&lang=en.

Descola, Philippe. 1996. "Constructing natures: Symbolic Ecology and Social Practice." In Nature and Society: Anthropological Perspectives, edited by Philippe Descola and Gisli Palsson, 82-102. London: Routledge.

Gutowski, Jerzy M. 2002. "Problem ochrony ekosystemów leśnych a gradacje kornika drukarza — wprowadzenie." ["The Problem of Preserving Forest Ecosystems and the Gradation of the Bark Beetle"] Prace Instytutu Badawczego Leśnictwa, Seria A 926: 5-15.

Haraway, Donna. 2003. The Companion Species Manifesto: Dogs, People and Significant Otherness Chicago: Prickly Paradigm Press.

Ingold, Tim. 2000. The Perception of the Environment: Essays on Livelihood, Dwelling and Skill. London: Routledge.

Jaroszewicz, Bogdan. 2016. "Kornik w Puszczy Białowieskiej - klęska czy naturalna dynamika lasu?" [The Bark Beetle in the Białowieża Forest — Disaster or Natural Dynamic of the Forest?]. YouTube video, 24:30, from a presentation delivered at Nocy Biologów [Biology Night] at the University of Warsaw on January 15. Posted by "Nauka dla Przyrody," January 21, https://www.youtube.com/watch?v=DvhWMwm-ORA.

Karpieszuk, Wojciech. 2017. "Marsz dla Puszczy" ["March for the Forest"]. Wyborcza, June 24. http://wyborcza. pl/7,75398,22004393, marsz-dla-puszczy-wyruszyl-z-pl-defilad.html?disableRedirects=true.

Lorimer, Jamie. 2012. "Multinatural geographies for the Anthropocene." Progress in Human Geography $36(5): 593-612$.

Lorimer, Jamie. 2014. "Experiments with the wild at the Oostvaardersplassen." ECOS 314 (35): 44-52.

Lorimer, Jamie. 2015. Wildlife in the Anthropocene: Conservation after Nature. Minneapolis: University of Minnesota Press. 


\section{Agata Kowalewska}

Maris, Emma. 2008. "Ecology: The Heart of the Wood." Nature 455: 277-80. dol:10.1038/455277a.

Mikulski, Andrzej. 2016. "Wierzę w Białowieżę! — o przedsięwzięciu w sprawie obrony puszczy rozmawiamy z dr Andrzejem Mikulskim" ["I Believe in Białowieża! — on the initiative in the defense of the forest with dr Andrzej Mikulski"]. By Katarzyna Konarzewska. Biotechnologia.pl, January 27. https:// biotechnologia. pl/bioetyka/aktualnosci/wierze-w-bialowieze-o-przedsiewzieciu-w-sprawie-obrony-puszczy-rozmawiamy-z-dr-andrzejem-mikulskim,15905.

Nauka w Polsce. 2017. "Naukowcy: wymiana gatunków w puszczy to proces naturalny." Fundacja PAP, March 22. http://naukawpolsce. pap. pl/aktualnosci/news,413537, naukowcy-wymiana-gatunkow-w-puszczy-to-proces-naturalny.html

Pracownia na rzecz Wszystkich Istot. n.d. Accessed September 19, 2017 http://puszcza.pracownia.org. pl/historia-ochrony-puszczy.

PTTK. n.d. "Puszcza Białowieska" ["Białowieża Forest"]. Accessed September 19, 2017. http://www. msw-pttk.org.pl/dokumenty/parki_ narodowe/biapn.html

Sienkiewicz, Henryk. 1882. Z puszczy Białowieskiej [From the Białowieża Forest]. Fundacja Nowoczesna Polska. https://wolnelektury.pl/katalog/lektura/z-puszczy-bialowieskiej/.

Sokołowski, Aleksander W. 2002. "Wpływ kornika drukarza na skład zbiorowisk leśnych w Puszczy Białowieskiej" ["The Influence of the Bark Beetle on the Content of Białowieża Forest"]. Prace Instytutu Badawczego Leśnictwa, Seria A 927: 17-30.

Szyszko, Jan. 2017. "Jan Szyszko dla Frondy wyjaśnia całą filozofię 'wycinki lasów'!" ["Jan Szyszko explains the philosophy behind 'deforestation' for Fronda!"]. By Tomasz Wandas. Fronda, April 27. http:// www. fronda.pl/a/jan-szyszko-dla-frondy-wyjasnia-cala-filozofie-wycinki-lasow,91825.html.

Wesołowski, Tomasz, Anna Kujawa, Andrzej Bobiec, Adam Bohdan, Lech Buchholz, Przemysław Chylarecki, Jacek Engel, et al. 2016. "Spór o przyszłość Puszczy Białowieskiej: mity i fakty. Głos w dyskusji." ["The Conflict on the Future of Białowieża Forest: Myths and Facts; A Viewpoint"] www.forestbiology.org 1: 1-12.

Wylie, John. 2007. Landscape: Key Ideas in Geography. Oxon: Routledge.

Zimmerer, Karl S. 2000. "The Reworking of Conservation Geographies: Nonequilibrium Landscapes and Nature-Society Hybrids." Annals of the Association of American Geographers 90 (2): 356-69. 